Baumgardner, W. (2019). Freescape of Tirana, Albania. Landscape Architecture Frontiers, 7(3), 136-145. https://doi.org/10.15302/J-LAF-1-050002

\section{阿尔巴尼亚地拉那的自由景观 FREESCAPE OF TIRANA, ALBANIA}

阿尔巴尼亚的首都地拉那在经历了重大政治变革后，正在采取 多种措施推动自身成为巴尔干地区的繁荣中心。当前的关键策略是通 过一系列多中心开发缓解市中心的拥挤压力。本项目试图从纺织品及 其图案等阿尔巴尼亚文化载体中挖掘那些可以体现地拉那人身份认同 感、记忆和声音的元素，将其在城市尺度上再现，并通过对一系列后 工业化多中心的开发重构地拉那的社会一政治叙事（图1）。

地拉那三面环山，是一个人口约 80 万的高密度城市（图2），污染 严重的拉纳河从市中心穿过。这条河曾一度是政治精英居住区和平民 区之间的屏障，但如今已是一处被遗忘的公共资源。位于市中心的斯 坎德培广场刚刚在2018年由比利时51N4E设计事务所翻新, 并于最近 获得了2018年欧洲城市公共空间奖 ${ }^{\mathbb{1}}$ （图3）。多条环路以斯坎德培广 场为中心向外扩张, 数条放射状的大道则穿过层层环路延伸至其他主 要城市。地拉那目前仍在使用含铅汽油和普通柴油, 缺少公交枢纽站 和火车接驳站，且直到最近才开设了第一个地下停车场。其公共空间 设计似乎在有意限制公众集会和大众娱乐，以及最重要的一点——表 达。由此可见, 地拉那的确是一座言论不自由的城市, 几乎无人敢于 在这里公开发表个人意见。在这一背景下，景观设计可以作为沟通与 表达的媒介，解放和重构城市公民个人与集体的潜力。

在20世纪，阿尔巴尼亚政府实施了多种形式的政治调控以实现支 柱产业的显著增长和生产的自给自足 ${ }^{[1]}$ 。在此期间, 恩维尔 - 霍查当局 建立了众多工厂 (如纺织厂和装配厂等) 以增加出口, 但公共空间和 公众自由也遭到剥夺和限制。1992年, 在民主政治制度的鼓舞下, 地拉 那开始尝试投资城市美化工程, 其中最著名的要数前任市长埃迪 - 拉马 发起的住宅小区外立面彩绘工程, 其试图通过鲜艳活发的色彩与图案为

\section{威廉·鲍姆加德纳}

景观设计师、规划师

摘要

阿尔巴尼亚首都地拉那是一座言论不自由且 身份认同感淡漠的城市。曾经动荡而黑暗的历史 使得地拉那公民对于政府的信任早已支离破碎。 那么，我们是否可以通过重构城市公共空间来更 好地帮助个人与集体发声? 本项目尝试从阿尔巴 尼亚纺织品中提取体现人们身份认同感、记忆和 声音的文化元素, 并将其在城市尺度上再现。虽 然该市正在实施的总体规划几乎没有考虑设置公 共空间，但其提出了一种新型的多中心开发模式。 项目以其中一个中心- - 座废弃的纺织厂为切入 点, 通过在多功能城市开发的背景下对场地的文化 记忆进行解读、提炼和表达，以实现集商业稃化、 住房供给、公共空间营造、社区农业培育和交通 导向型开发等为一体的综合性目标。该项目希望 通过修复土壤、引入新的劳动形式，以及进行社 区开发来挖掘场地的过去, 进而改写地拉那的命 运。通过解锁记忆和重构城市肌理, 一种可供人 们自由发声的开放的公共空间便形成了。

\section{关键词}

社会公平；后工业化；社区开发；都市主义；记忆

翻译 李慧彦 王胤瑜

TRANSLATED BY LI Huiyan WANG Yiny

\section{William BAUMGARDNER*}

Landscape Designer and Planner

*Corresponding Author

* Corresponding Author Address. 54 Old Colony Ave, Boston, MA 021

\section{ABSTRACT}

Tirana, capital of Albania, is a city where voices are silenced and identities remain opaque. With a tumultuous and dark history, Tirana's political landscape, which is inherent to public trust, has been fractured. Then, how can the public realm be reconceived to better express individual and collective voices? This project explores how cultural forms of identity, memory, and voice found in Albanian textiles can be interpreted at the urban scale. The master plan currently implemented in the city scarcely recognizes public spaces but allocates new poly-center developments. Grounding the project in one of these poly-centers, a derelict textile factory, cultural memory is interpreted, extracted, and manifested in a multi-faceted urban development. Such a process aims to operate as a business incubator, housing and public space, community agriculture, and transitoriented development. This project aspires to reposition the city's history by excavating the past through soil remediation, new forms of labor, and community development. Unlocking this memory and restructuring its texture will form a liberated, vocal, and free public realm.

\section{KEY WORDS}

Social Equity; Post Industralization; Community Development; Urbanism; Memory 
(1) 有关此项目的详细 获奖信息，请访问 PublicSpace官方网站的 作品列表页面。

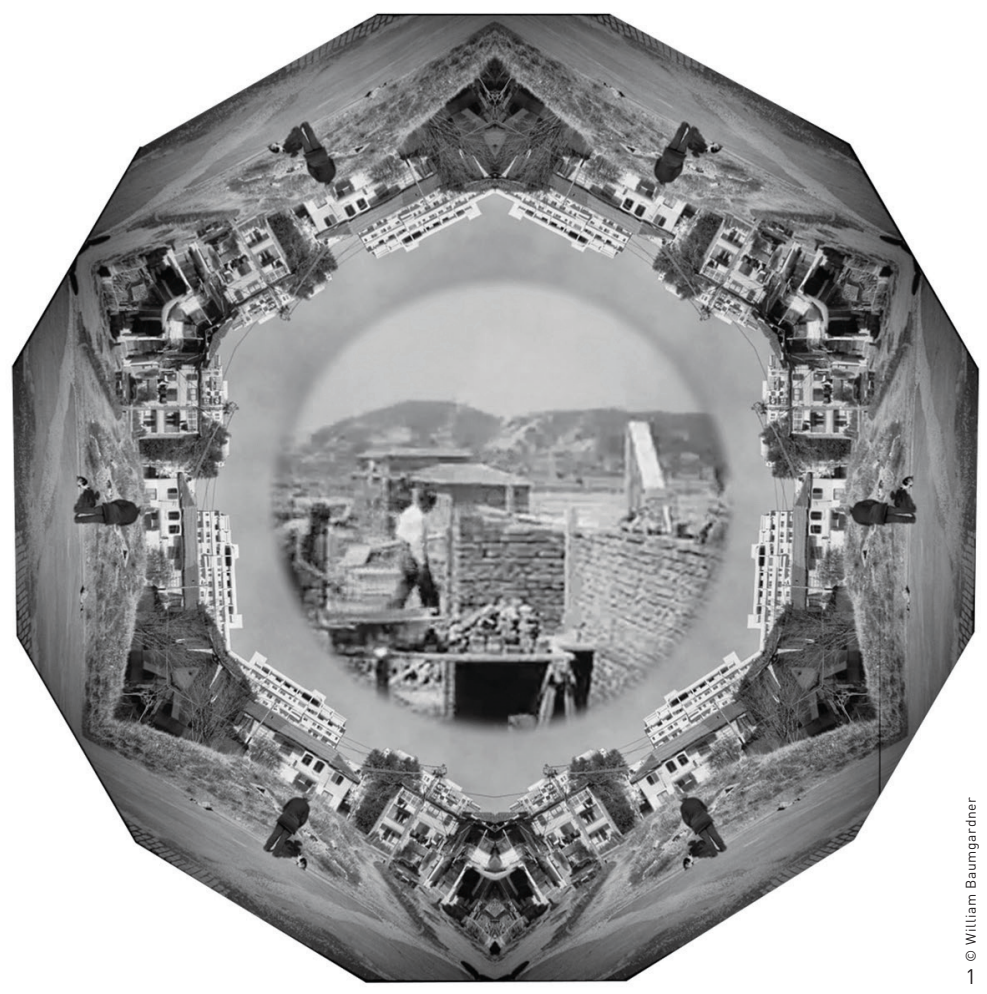

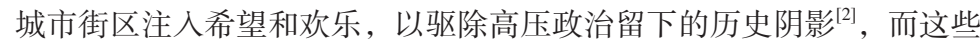
图案现在已然磨蚀破损（图4）。如今, 在现任市长埃里昂 - 维利亚吉 的推动下，地拉那启动了一项重要的公共空间投资项目，计划在市中 心开展一系列大规模公共基础设施工程（图5）。即便如此，地拉那公 共空间的人均占有面积仍仅有 $2 \mathrm{~m}^{2}$ ，远低于 $7 \mathrm{~m}^{2}$ 的欧盟平均水平，使用 率也较低（图6）。那么，这座高密度城市应当采取什么方法、在哪些 方面对公共空间进行再投资?

2017年, 维利亚吉市长与哈佛大学设计研究生院签署了一项联 合研究计划, 以进一步细化由意大利米兰斯坦法诺 - 博埃里建筑设计 事务所领导的团队制定的“地拉那2030”城市总体规划。这版制定于 2016年的规划以建筑开发及导则制定为主要内容，但对于整体公共空 间及景观的关注不足：其提出新建一项环绕城市的实体绿化工程 “轨道森林” , 并将减轻中心区发展压力、促进 “多中心” 分散式增 长作为核心目标; 这些新中心大多是后工业遗址，但该规划并未充分 认识到对其进行改造和重新利用将面临的挑战。本研究项目旨在回应 这一问题，并选取总体规划指定的第一个中心一一坎比纳特厂区作为 研究对象。

坎比纳特（在阿尔巴尼亚语中意为 “联合”）厂区位于地拉那市
坎比纳特厂区的现状 (外图) 与其历史影像 中的建设情景 (内图) 形成了对比。

2. 从达捷特山向西南方眺望 地拉那致密的城市肌理

1. Examining historic footage of Kombinat's construction (inner) through the presen conditions (outer)

View of Tirana looking southwest from Moun Dajti illustrates the density of the city.

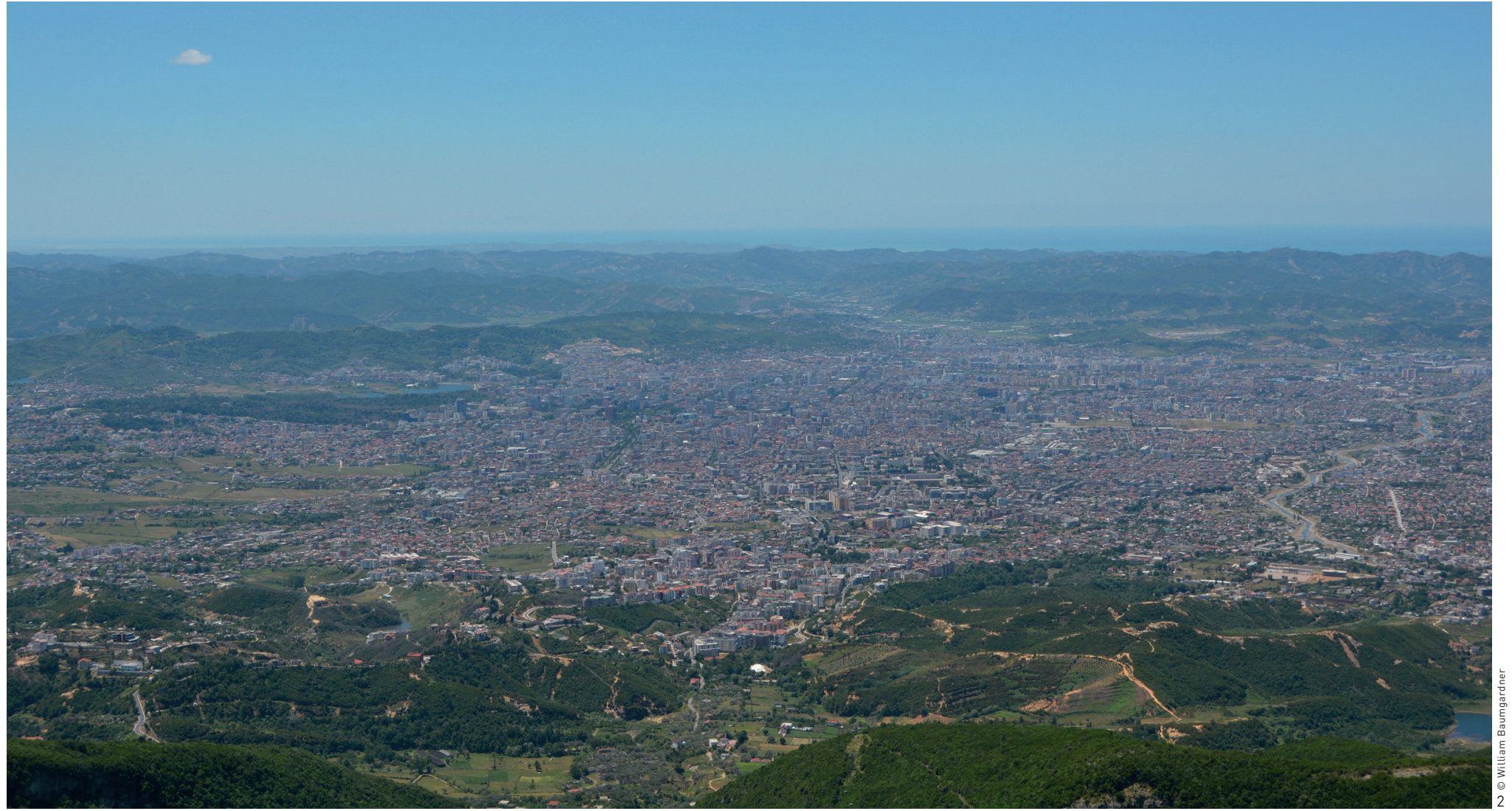




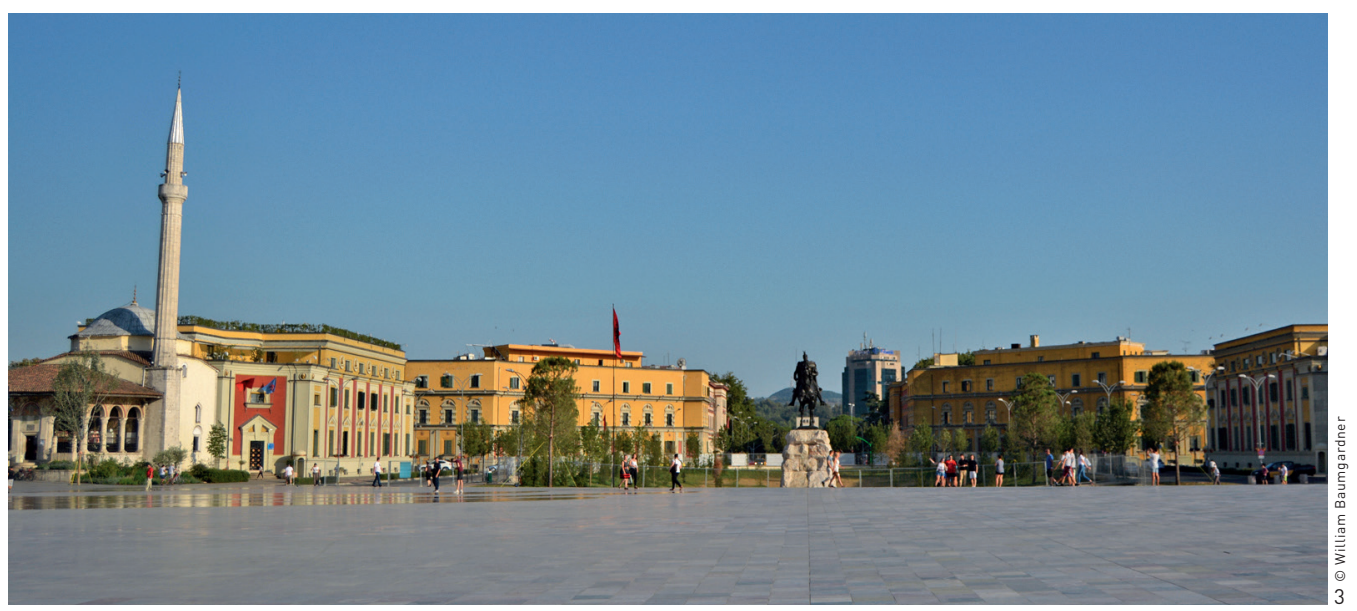

3. 近期翻新的斯坎德培广 场作为一处新的公共空 间, 为城市中心再次注 入了活力。

4. 埃迪 - 拉玛发起的外立 面彩绘工程中绘制的图 案如今已经开始暗淡、 磨蚀, 但它们曾试图为 市民带来希望和欢乐。

5 . 新市场是地拉那快速建 成的重要公共设施之一。
3. The recently renovated Skanderbeg Square revitalized the heart of the city with new public space.

4. The Rama era murals are now in a state of decay after attempting to bring hope and joy into the city.

5. The New Market is one of the major public realm projects that have been completed rapidly in Tirana.
区边缘与外围山区的交界处, 原为一处废弃的纺织厂, 建于 20 世纪40 年代后期，反映了那一时期阿尔巴尼亚的政治意识形态、社会生产情 况、工业化进程, 以及自给自足的生活方式。时任领导人恩维尔 - 霍查 相信, 在当时的政治结构下, 这类工厂将助力阿尔巴尼亚走上自给自足 的现代化之路 ${ }^{[3]}$ 。然而，1992年的政变不仅摧毁了坎比纳特厂区，更使整 个阿尔巴尼亚陷人动荡，工厂及其周边区域逐步成为非正式社区的聚集 地。由于这里基础设施落后、大量建筑与设施年久失修, 部分居民不 得不依靠私接水管与电线维持生活（图7）。

此外，坎比纳特厂区内还有一座维护不善的废弃火电厂，其遗留 的粉煤灰渣已经渗人并污染了土壤。对地拉那而言, 土壤是历史记忆 的载体和地方兴衰的见证，因此，对受污染的土壤与场地进行修复与 改造便成为了其复兴之路的第一步。唯有如此，坎比纳特厂区、城市 中的其他中心，以及整座城市才有望改写自身命运，从而创造一个新 的未来。

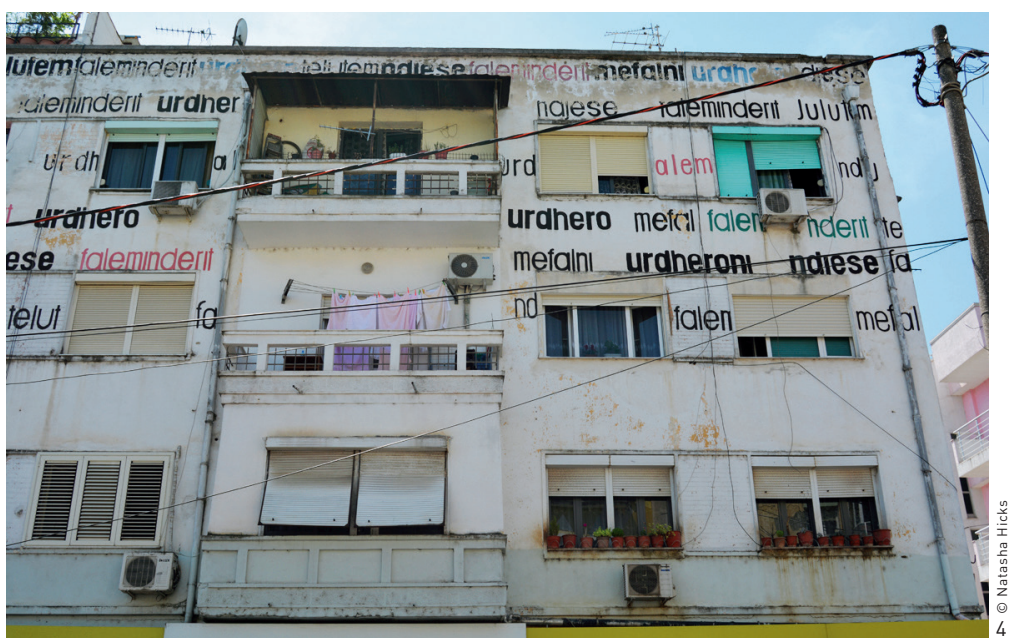

为使坎比纳特厂区能够持续稳定地为地拉那居民提供工作机会, 设计团队设想在这里建立一处多功能社区 (图8)。“地拉那2030”总 体规划为该区域赋予了居住、办公和商业空间多种功能。目前, 地拉 那有超过30\%的18 34岁青年没有工作; 作为阿尔巴尼亚的主要城市, 地拉那虽然拥有大量的年轻人口, 却缺少足够的吸引力将他们留住。 如果能将坎比纳特厂区成功塑造为一处基础设施完善的居住空间、一 个孕育初创企业与青年文化的摇篮, 便有望为地拉那市带来更多的创意 活力、更高的连通性, 以及新的城市记忆。在该项目中, 团队试图重构 “纺织品” 的概念一一它不再是坎比纳特厂生产的商品, 而是一个连接 体：通过将纺织图案拉伸至三维空间, 其可以作为建筑和景观形态, 以 及对人口和各类发展驱动因素进行布局的参考（图9，10）。

项目将坎比纳特厂区的中心广场一一加里波第广场作为设计的切 人点。时至今日, 工人们和社区居民都是先乘公交或步行到这里, 再 进人工厂。设计方案将这一公共空间打造为一处绿树成荫的社区集会

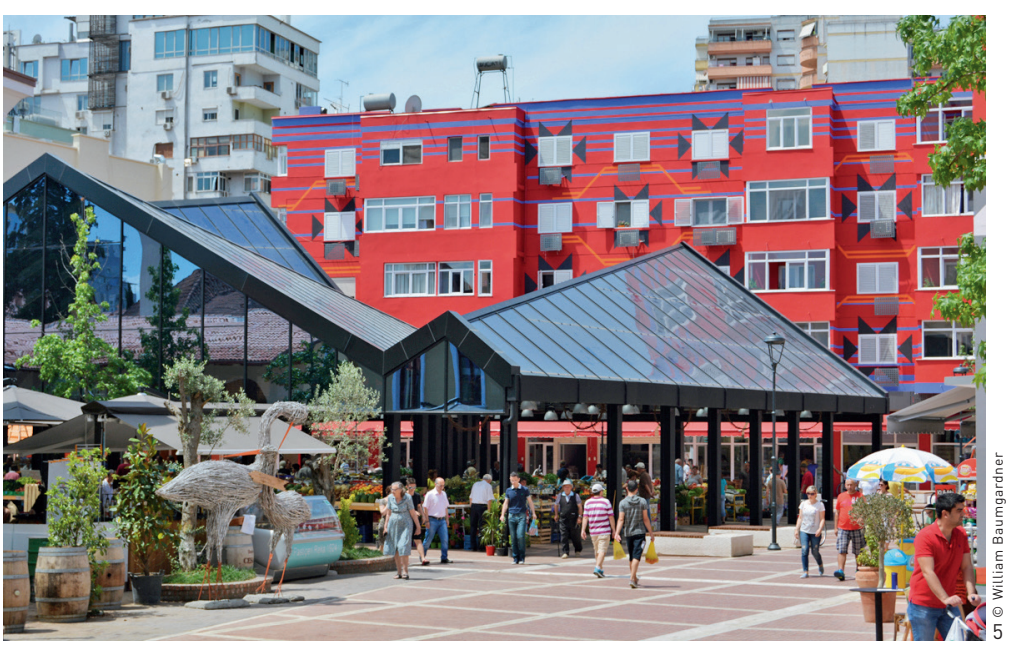




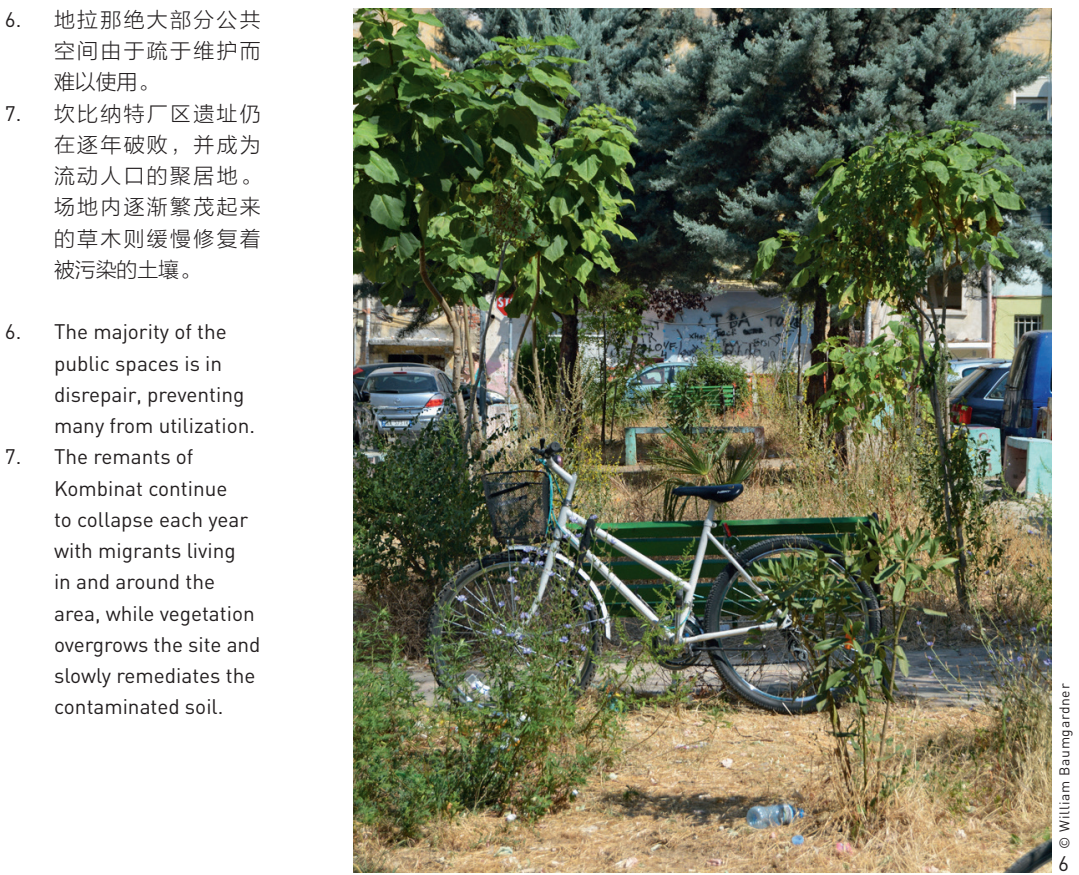

场所（图11），并遍植茂密的绿色植物用于净化土壤。与广场相接的 大道被改造成一种新型林荫道, 其两侧设有专用的自行车道、落座区 和日常社交活动空间（图12）, 可被视为街区向道路的延伸, 约占一 条机动车道的宽度, 使原本的三车道变为双车道。这种新型道路可以 从坎比纳特厂区一直延伸至市中心。

穿过广场旁的加里波第大门，便来到了集住房、公地和工厂于一 体的新型多功能区。为了给原本的非正式居民和新居民提供住处, 设 计团队规划了一系列复合用途的多户集合住宅群，可供800人使用。原 有厂房被部分拆除，以提升步行便利性，并留出更多空间用于环境修 复与美化; 保留下来的厂房则被改造成规模不一的创客空间、企业睬 化器及多种必需的城市便利设施, 为年轻人提供在本地长期发展的条 件, 以将他们留在地拉那。如此一来, 整个工厂区被转化为居民社交 空间。公地是衔接这些新空间的桥梁（图13），其原本是一处工厂遗 址, 在本设计方案中用于集中修复环境。设计将部分区域挖开并修建 为下沉空间, 可供人们亲近土地, 感受城市历史; 挖出的土壤可用于 塑造新的微地形, 并栽植丰富的绿色植物来固定和净化土壤; 此外, 旧火电厂剩下的砖块可以制成石笼, 用来辅助塑造和加固地形。在改 造其他区域时, 粉碎的砖块还可以用作混凝土或其他永久工程建设的 新地基。

最后，通过林荫小径可到达社区农场。这里竩立着昔日火电厂的 残迹 (图14), 构筑物仍在逐年不断倒塌。因此, 设计方案计划将这 些残余建筑拆除, 空出土地供社区居民进行农业种植与自主管理, 如 种植向日葵和苜宿幼苗来修复土壤, 或通过种树将社区农场与 “轨道 森林” 相连。贯穿场地的自行车道可将地拉那市区、坎比纳特厂区与
“轨道森林” 无缝衔接。

总体而言, 上述每处场地的设计都为环境、社交和文化修复创造 了条件。随着地拉那的政治历史翻开新的篇章, 坎比纳特厂区也将重 新成为城市的繁荣中心之一。新建的自行车和机动车交通基础设施使 该地区不再是与外界隔绝的孤岛（图15)。

在研究地拉那的城市肌理时, 设计团队将城市中的每个人视为 “纺织者”, 是他们将建筑、基础设施、景观等元素编织在一起, 使 整座城市成为一幅更加恢弘的图景。另一方面, 这种肌理或图景也是 千人千解的, 每个人都以其独特的方式利用城市空间—这些不同的 方式通过聚集与规模化, 形成了更大的认同与感知网络。身为 “纺织 者” 的居民们在建成环境中创造属于自己的记忆, 发出自己的声音, 并将之传达给家人、朋友和同事。在记忆、行为和习惯形成的过程 中，城市的活力也得以复苏。

通过多中心改造, 城市也在进行自我重构; 但发掘与再现每处 场地的独特历史仍然至关重要, 因为这意味着唤醒埋藏在建筑、自然 环境和人们心中的记忆。正如在地拉那享誉数百年的纺织品中, 每一 针每一线都有其意义, 它们共同织就了恢弘精美的图案; 缺失了其中 任何一个主要元素, 都可能使编织肌理变形、磨损或碎裂。记忆对城 市及其居民的影响也是如此, 因而成为了景观设计可以借助的关键力 量。倡导并利用这些记忆有助于创造辉煌的未来。通过解锁记忆并重 构割裂的城市空间, 一种开放的公共空间便形成了一一在这里, 人们 可以畅所欲言。LAF

致谢

哈佛大学设计研究生院景观设计系主任安妮塔 - 贝里兹巴提亚教授作为作者导师, 为文中研究项目提供了 宝贵的指导与建议, 在此表示诚挚的感谢。

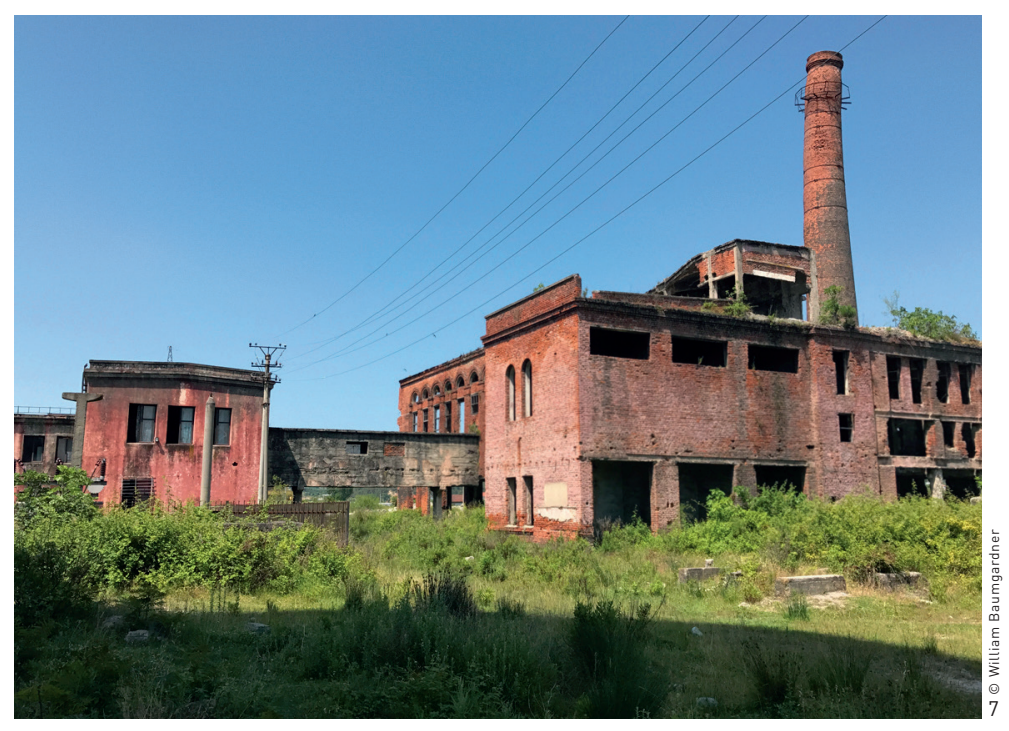


In the wake of major political shifts, Tirana, capital of Albania, is implementing several measures to catalyze itself as a thriving hub in the Balkan region. The key strategy is a series of polycenter developments aiming at relieving pressures from the already congested and dense downtown core. This project explores how cultural forms of identity, memory, and voice, found in Albanian cultural expressions, such as textiles and their patterns, can be interpreted at the urban scale. This project also reconstructs the socio-political narrative beginning from these post-industrial poly-centers (Fig. 1).

Tirana is home to a population of approximately 800,000 within a dense urban fabric (Fig. 2). It is located in a valley with mountains surrounding on three sides. The heavily polluted Lana River cuts through the center of the city. This river once stood as a barrier between the political elite and the rest of the city, but is now a neglected utility. The city has a central square called Skanderbeg Square, which was just renovated in 2018 by the Belgian firm 51N4E and was recently awarded the 2018 European Prize for Urban Public Space ${ }^{\mathbb{1}}$ (Fig. 3). A series of ring roads with spikes emerging from Skanderbeg Square lead to other major cities. Tirana continues using leaded gasoline and regular diesel, lacks a central bus station, has no train connectivity, and recently opens its first underground parking garage. It has purposefully designed its public space to prevent gathering, recreation, assembly, and most of all, expression.

Tirana is indeed a city where one's voice is silenced; hence, it exemplifies a silenced public realm. Public expression of opinion is non-existent in Tirana. Therefore, landscape architecture can act as an agent of reconciliation and expression in this city to liberate and reconstruct both personal and civic potential.

In the 20th century, Albania underwent multiple forms of political control from leaders responsible for creating a selfsufficient state and major industrial progress and growth ${ }^{[1]}$. During that period, leaders, such as Enver Hoxha, constructed many factories to increase exports (textile production, assembly, etc.). However, public space and public freedom were stripped and controlled. In 1992, the emergence of a democratic political system inspired the city to attempt to invest in civic
(1) For detailed award statement of this work, please search the Works page in the official website of PublicSpace.
8. 本设计方案旨在将坎比纳 特厂区打造成活跃的创新 与生活枢纽，并使其与地 拉那市中心以及“轨道森 林” 连接起来。

8. The overall site design unites the poly-center with the core of the city and the proposed Metrobosco while creating a dynamic hub of innovation and living.

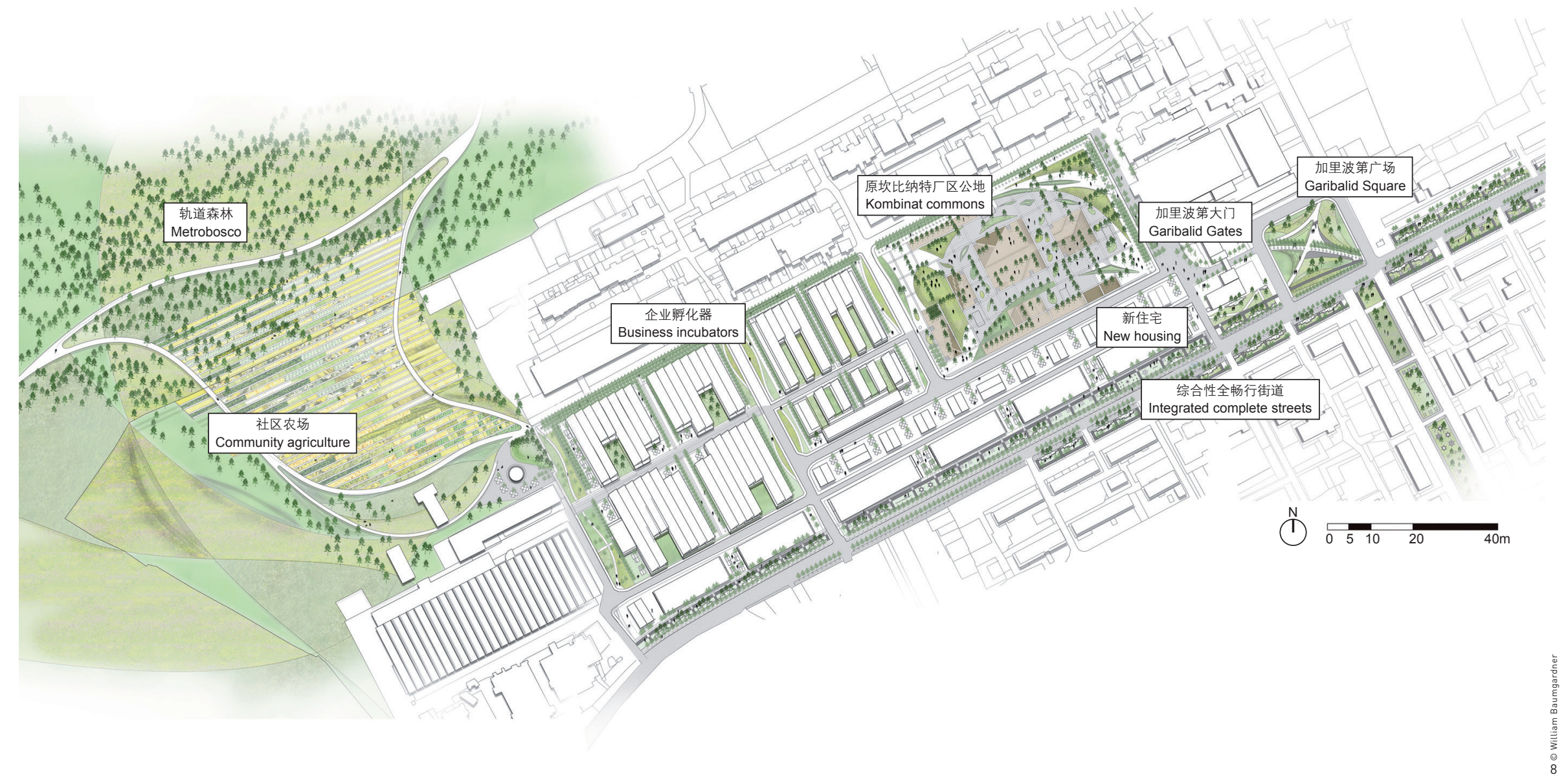


小型纺织图案示例

Small-scale thread pattern examples

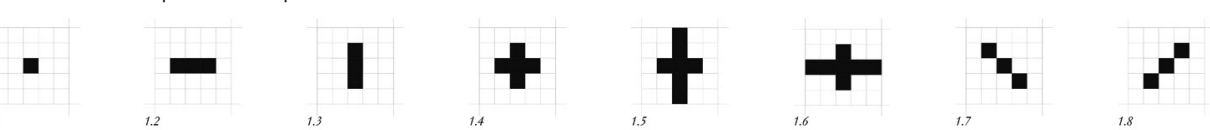

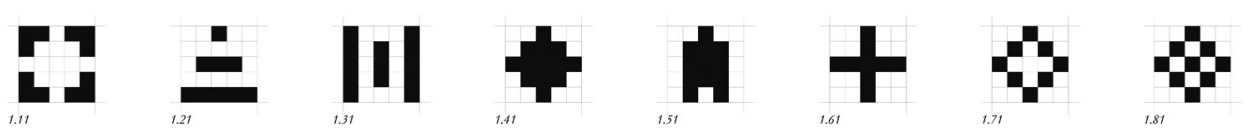

$\mathrm{E}$

中型纺织图案示例

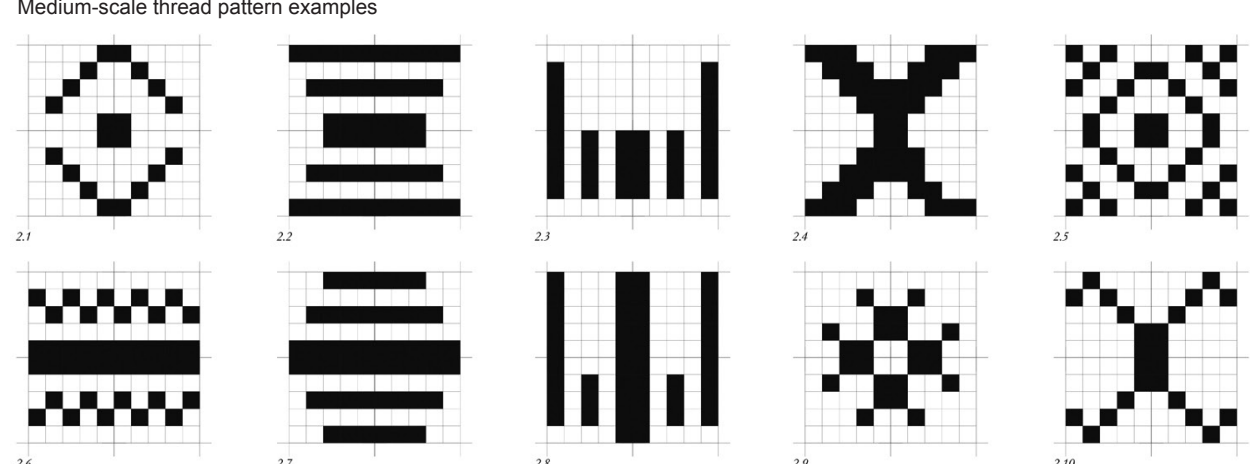

大型纺织图案示例

Large-scale thread pattern examples
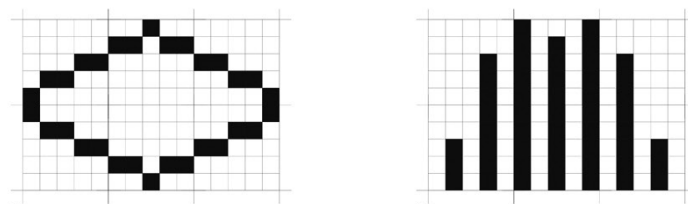

b)

क
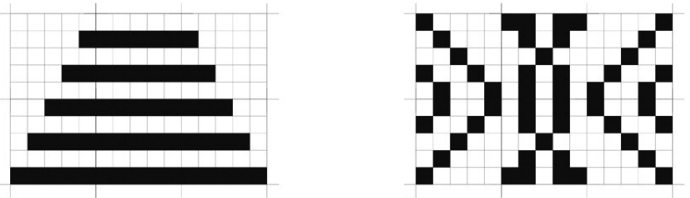

Mö
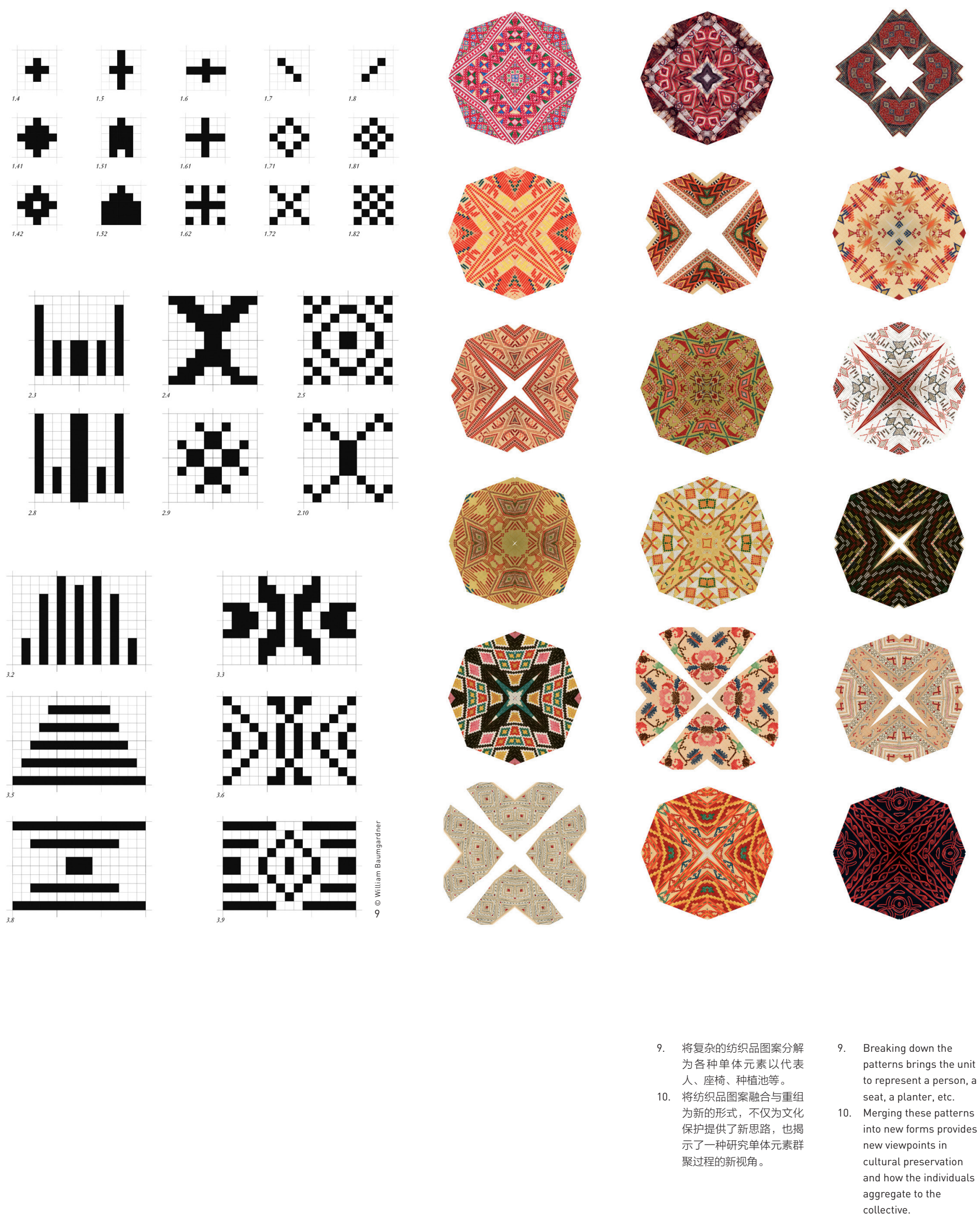

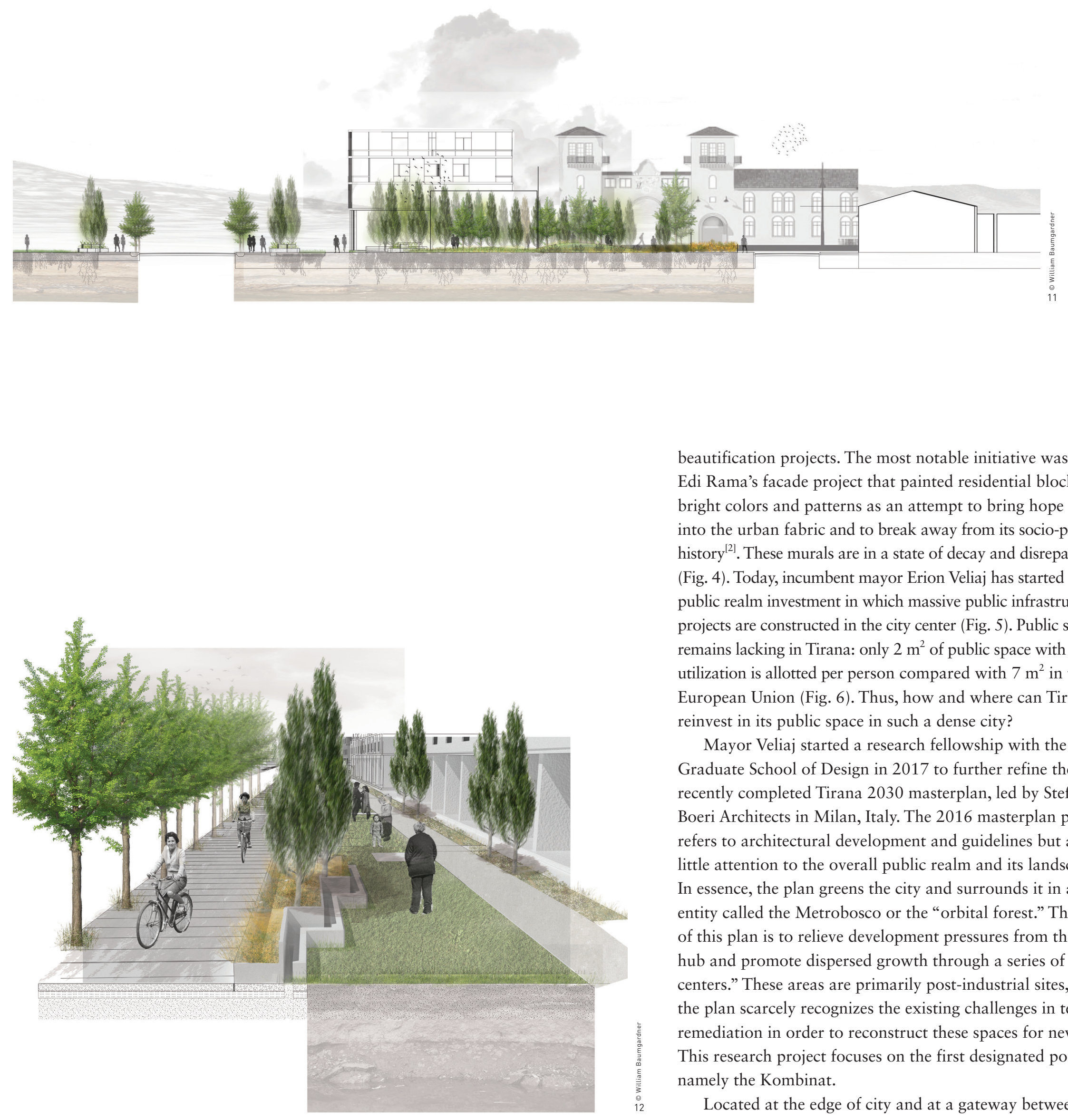

beautification projects. The most notable initiative was mayor Edi Rama's facade project that painted residential blocks with bright colors and patterns as an attempt to bring hope and joy into the urban fabric and to break away from its socio-political history ${ }^{[2]}$. These murals are in a state of decay and disrepair now (Fig. 4). Today, incumbent mayor Erion Veliaj has started a major public realm investment in which massive public infrastructure projects are constructed in the city center (Fig. 5). Public space remains lacking in Tirana: only $2 \mathrm{~m}^{2}$ of public space with poor utilization is allotted per person compared with $7 \mathrm{~m}^{2}$ in the European Union (Fig. 6). Thus, how and where can Tirana reinvest in its public space in such a dense city?

Mayor Veliaj started a research fellowship with the Harvard Graduate School of Design in 2017 to further refine the recently completed Tirana 2030 masterplan, led by Stefano Boeri Architects in Milan, Italy. The 2016 masterplan primarily refers to architectural development and guidelines but allots little attention to the overall public realm and its landscape. In essence, the plan greens the city and surrounds it in a new entity called the Metrobosco or the "orbital forest." The core of this plan is to relieve development pressures from the city hub and promote dispersed growth through a series of "polycenters." These areas are primarily post-industrial sites, but the plan scarcely recognizes the existing challenges in terms of remediation in order to reconstruct these spaces for new use. This research project focuses on the first designated poly-center, namely the Kombinat.

Located at the edge of city and at a gateway between 

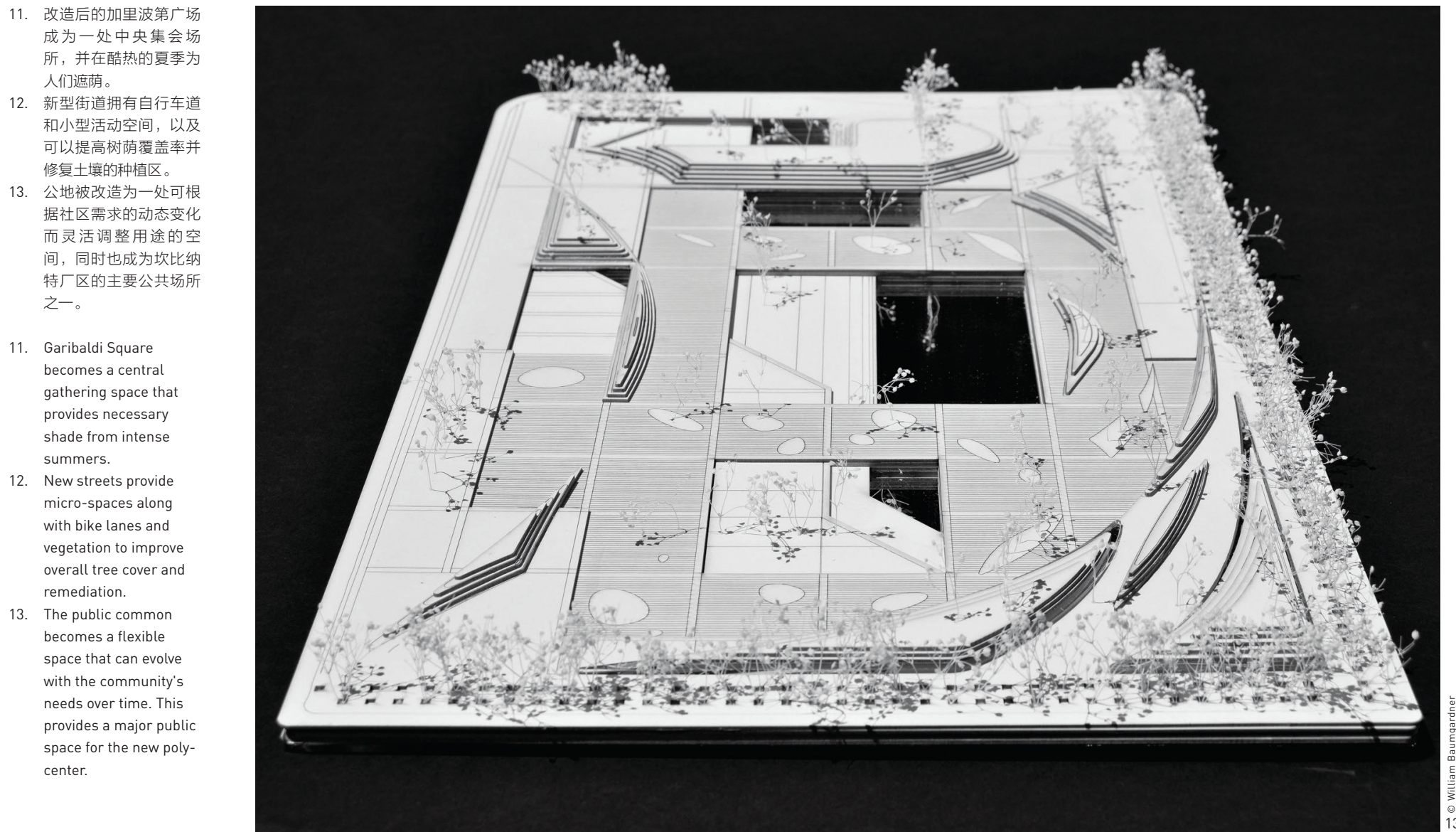

the mountains, a derelict textile factory stands, namely the Kombinat (or "to combine" in Albanian). Completed in the late 1940s, this textile factory was a testament both to political ideology and to Albanian production, industrialization, and self-sufficiency. Enver Hoxha, the head of Albania at that time, believed that these factories would pivot the direction and history of the country into a modern and self-sustaining one under the political structure ${ }^{[3]}$. However, the political shift in 1992 crushed the factory, along with the stability of Albania. Hence, the site has been inhabited by informal communities living in and around the factory. Infrastructure at the Kombinat is poor. Thus, several residents tap water and electric lines for personal use while suffering from crumbling buildings and facilities (Fig. 7).

Moreover, this area is contaminated. The remains of a coal plant here leached into the soil owing to years of use, neglect, and abandonment. Soil is a reflection of the past and a keeper of memory, as well as a witness to change and evolution, showing the rise and fall of cities and regimes. Thus Tirana must begin from the ground and move upwards to further push the development of the city. By remediating and reconstructing the soil, Kombinat, the other centers, and the city can begin to reconstruct a new future and reposition its history.

Given that Kombinat is going to be a steady source of jobs for residents of Tirana, the design team envisions the space as a multi-faceted community (Fig. 8). The Tirana 2030 masterplan designates this zone to provide housing, offices, and commercial spaces. Currently, over $30 \%$ of the population in Tirana aged $18 \sim 34$ are unemployed. The youth are concentrated in Tirana as the main city, but many of them see no reason to stay. By repurposing Kombinat into a space that improves the overall community infrastructure for residents and into a civic anchor that promotes start-ups and youth culture, the city can provide outlets for creativity, connectivity, and a new thread of urban memory. Here, we intend to reconstruct the concept of the textile not as a commodity as it once was in Kombinat but as a 
unifier. By stretching this perception of the fabric into a 3D form, this idea can be applied as references to the form of architectures and landscapes, and the distribution of people and catalysts (Fig. 9, 10).

The project begins in the central square of Kombinat, Garibaldi Square. This area was and is still the location where workers and the entire community would arrive via bus or by foot before they enter the factory. The proposed design considers this public space as the center for community gatherings with tree shades (Fig. 11). Dense greeneries are planted throughout the area to help clean the soils over time. The square is then connected into a new boulevard typology with spaces dedicated for bike lanes, seating areas, and informal social programs (Fig. 12). Each series of blocks with these spaces is then extended, thereby reducing the road from three lanes to two. This boulevard typology can extend from the Kombinat and into the city center.

Moving through the Garibaldi Gates welcomes one into the new mixed-use area of housing, public commons, and factories. To provide housing for informal communities and new residents, a series of mixed-use typologies and multi-family clusters will be built up for 800 residents. Portions of the factories are then removed to provide better pedestrian access and spaces for remediation. Existing factories will be converted into maker spaces and business incubators of various scales with critically needed amenities to the city, providing spaces for long-term growth to encourage the youth to stay in Tirana. The new design transforms the factories into social spaces that generate opportunities for residents. The public commons bridge these new spaces together (Fig. 13). Built on the remnants of a former factory, this site will be transformed into a space for collective remediation. Portions of the commons are carved out to bring people down into the soil and a moment in the city's history. The cut from these spaces is then translated into new landforms with abundant greeneries that stabilize and clean the soil well. To contain the soil and maintain the commons, the proposed design uses leftover bricks from the old coal factory and repurpose them into gabions. Crushed bricks can also be utilized to provide a new layer on which concrete and other permanent features can be implemented while the other areas are under reconstruction.

Lastly, the connective alleys of trees lead to the community agricultural area. Here, remnants of the coal factory remain (Fig. 14). However, structures increasingly fall and collapse annually. Therefore, the proposed design dismantles the rest of these buildings and provide spaces for the community to remediate the soil by planting sunflower and alfalfa seedlings. These spaces can be managed independently by the community for agricultural purposes. The plots can also be planted with trees, which connect the new Metrobosco. Bike lanes throughout the site provide users with a seamless transition from the city to the Kombinat and to the Metrobosco.

Together, each site provides areas for environmental, social, and cultural remediation. The Kombinat is converted into an anchor community similar to what it was before in the new chapter of Tirana's political history. The site is no longer isolated because it is connected to the Metrobosco and the city center through bike and vehicular infrastructures (Fig. 15).

Investigating this urban fabric, the design team posits that the person or individual is the "weaver." The city is a large fabric consisting of elements, such as buildings, infrastructure, and landscape, all brought together into a larger pattern. However, to each person, this urban fabric or pattern is different. Each individual distinctly utilizes the urban realm, which aggregates and scales into a larger mesh of identity and perception. As the "weavers," residents create their own memories and voices in the built environment. They translate these perceptions to their families, friends, and colleagues. This construction of memory, performance, and ritual contributes to the dynamism of a city.
14. 火电厂的遗迹被改造为 社区农场, 并成为连接 坎比纳特厂区与 “轨道 坎比纳特厂区与 “轨道

15. 图中展示了坎比纳特厂 区与地拉那市其他区域 的连接方式, 以及多中 心新型开发布局。

14. The site of coal plant over time becomes a space of community space of community agriculture and Kombinat through the Metrobosco.

15. Kombinat connects to the rest of the city and shows how each polycenter can generate new development.

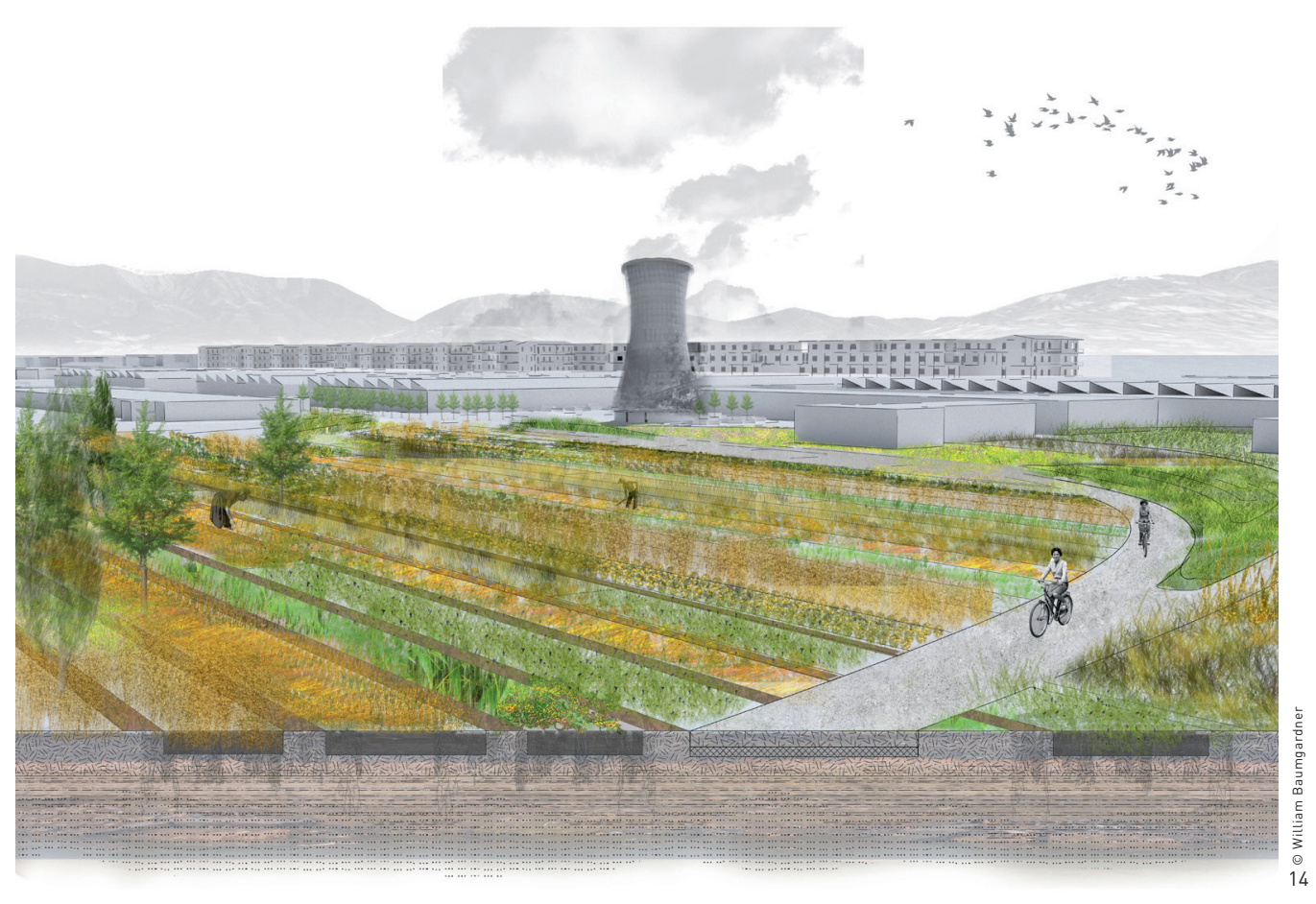




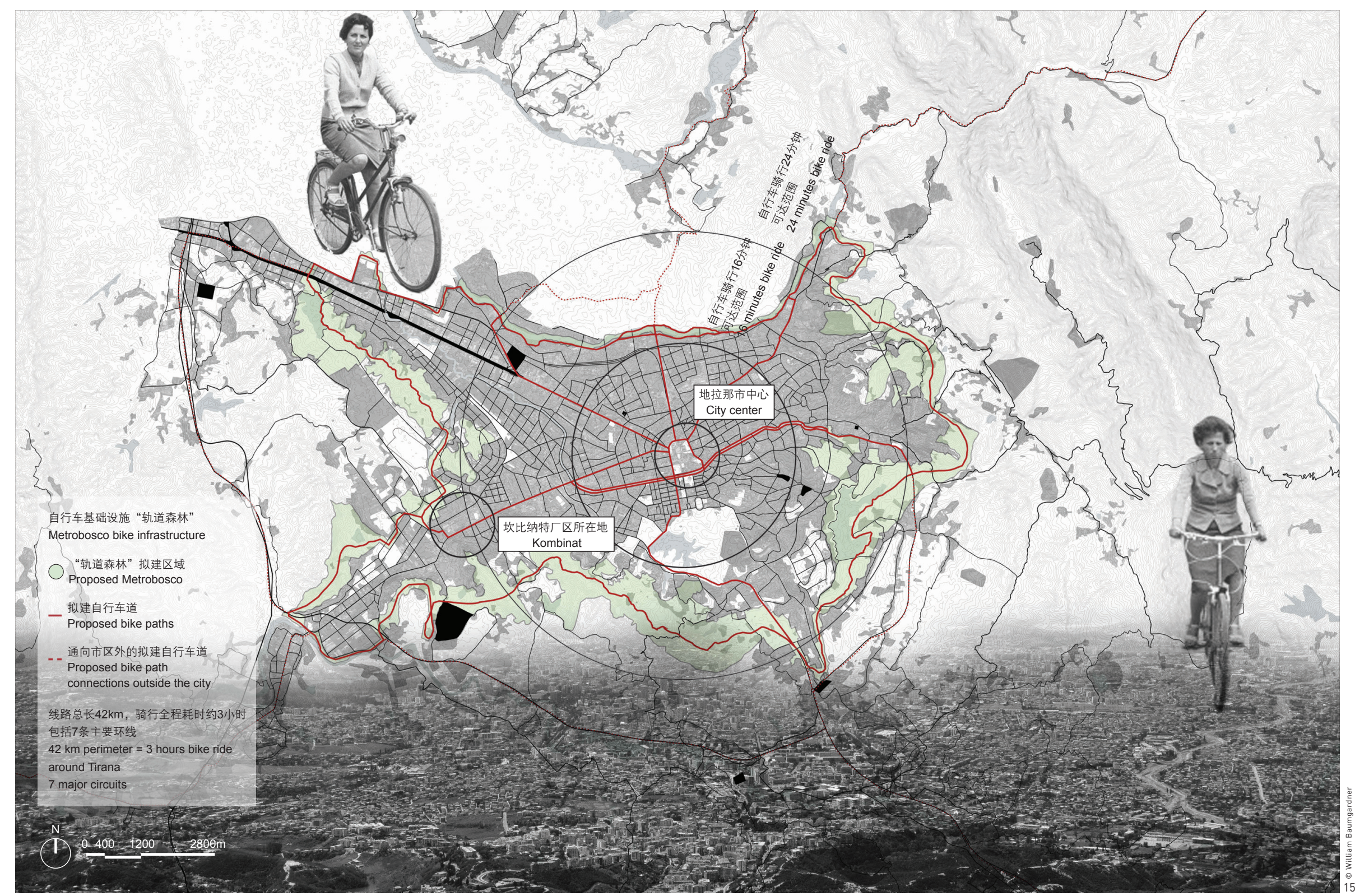

By reconstructing these poly-centers, the city also reconstructs itself. However, addressing and incorporating each unique history into each site is essential to reflect built, environmental, and human memory. To the textiles that have prevailed in Tirana for centuries, each thread and pattern serves a purpose and frames a large picture. Without any of the major elements, the fabric may weather, fray, or tear. Memory's influence on humans and cities is a similarly critical force to be addressed within landscape architecture, and championing and applying it will provide a solid future. Unlocking this memory and restructuring its debris and space will allow a liberated public realm — one that is vocal and free. LAF

\section{ACKNOWLEDGEMENT}

The author sincerely acknowledges his advisor, Annita Berrizbeitia, Chair of the Department of Landscape Architecture, Harvard Graduate School of Design, for her important guidelines and suggestions to the research in this article.

\section{REFERENCES}

[1] Schmitz. A. Kennedy. P. L. \& Schmitz. T. G. (Eds]. [2016). Food security in a food abundant world: An individual country perspective (First ed., Frontiers of Economics and Globalization; Volume 16). Bingley Emerald Group Publishing Limited.

[2] Bakallbashi, G., Mitro, E., \& Gjinali, E. (2010). Tirana, Beyond Color. In G. Doherty (Ed.), New Geographies 3: Urbanisms of Color (pp. 18-19). Cambridge: Harvard Graduate School of Design.

[3] Za, L. (2012). Kombinat: Storia e vita quotidiana di un quartiere simbolo di Tirana. Nardò: Besa. 